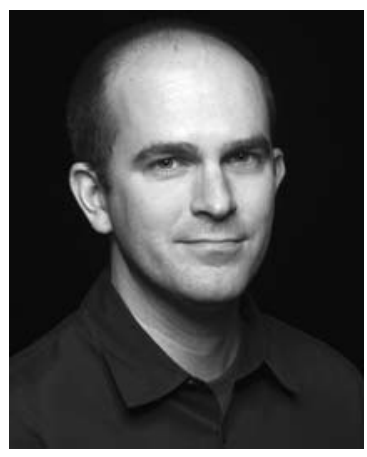

\title{
A Conversation with Christopher Vakoc
}

\author{
Interviewer: Paula Kiberstis
}

Senior Editor, Science

Christopher Vakoc is an Associate Professor at the Cold Spring Harbor Laboratory.

Paula Kiberstis: Could you tell us a little bit about the history of transcription in cancer research and why you feel it's a good target for therapy?

Dr. Vakoc: What many decades of cancer research have taught us is that there are some fundamental hallmarks of cancer biology that I think everyone in the field recognizes. What's clear is that behind every hallmark feature of a cancer cell is an aberrant transcriptional program, which is not surprising. All of biology is driven by changes in gene expression, and cancer biology is no different. There's a kind of obviousness to the role of transcription in cancer.

More compelling, though, is what the sequencing of cancer genomes has taught us about the causes of cancer. There are old examples, like p53 and myc; those heavily mutated genes in cancer are transcription factors. We've known that for ages. There've also been recent discoveries that remind us of the importance of transcription, specifically the discovery that almost all human cancers have mutations of chromatin regulators - the so-called "epigenetic regulators"-involved in transcription, as well. This discovery was made in the last 6 years or so. The new wave of evidence behind the role of transcription is the discovery that there are noncoding mutations in cancer genomes that are incredibly common, which are often missed when you sequence only exomes in protein coding genes. We're realizing that the binding sites of transcription factors are also heavily mutated in different malignancies. You put all these older and more recent lines of evidence together and it's really indisputable that transcription abnormalities act in cancer as a driver mechanism.

Paula Kiberstis: Five years ago, you published an influential paper in which you and a group in Boston independently arrived at the same protein, BRD4 (bromodomain-containing protein 4), as a target for cancer. Could you tell us about that and the story of how that happened?
Dr. Vakoc: If one is aware that aberrant transcription is a driver of cancer, the obvious usefulness of that information is the idea that cancer cells are going to be vulnerable to perturbations of transcription. My whole laboratory has been built on that hypothesis. When I came to Cold Spring Harbor, we went hunting for vulnerabilities in transcription control that cancer cells possess but that normal cells do not. Part of the drive coming to Cold Spring Harbor was to use RNA interference (RNAi) screening that was pioneered in part by Greg Hannon and Scott Lowe here. We set about systematically knocking down every chromatin protein in an aggressive cancer called acute myeloid leukemia. We were asking which chromatin proteins leukemia cells needed that normal cells do not. This led us to BRD4. Targeting BRD4 had a catastrophic phenotype on leukemia and less of an effect on normal cells. It was a discovery based on a genetic screen.

There was undoubtedly a lot of interesting biology behind it, so the therapeutic relevance of this was really off on the horizon, at least in those early days. That's when my encounter with Jay Bradner took my scientific career, and my life, in a totally unexpected direction in the best possible sense. My Ph.D. advisor knew about our BRD4 observation with our RNAi screen and alerted me that Jay Bradner just published a paper in Nature in 2010 describing JQ1, the first small molecule I was aware of that directly targets BRD4. This was just the ultimate serendipity, when lightning strikes in the best possible fashion.

Paula Kiberstis: You were not aware of this paper beforehand or you just didn't relate it to what you had discovered?

Dr. Vakoc: Apparently, in Pharma there's been an effort going on in the background that I was unaware of to make molecules against this protein. Jay Bradner was the first to take these molecules from behind the iron curtain of what's happening in secret in Pharma. He brought these

(C) 2016 Vakoc. This article is distributed under the terms of the Creative Commons Attribution-NonCommercial License, which permits reuse and redistribution, except for commercial purposes, provided that the original author and source are credited. 
molecules out into the public and started distributing them. He's become very famous for this open source distribution of JQ1. We were one of his first customers. It was a very exciting phone call where I told Jay all our results from our RNAi screen. Literally, the next day he sent us huge quantities of JQ1 and we started treating our leukemia mouse model with this compound, thinking that our RNAi screen predicted that this should be a good target. Remarkably, it was. We just went straight for the killer experiment and it worked. It really just stunned us that this could be true.

Jay has become a very dear friend and one of my closest collaborators. Working together in these animal models of leukemia, we showed that this is actually a respectable, preclinical, drug-like molecule. Defining the mechanism was kind of the cherry on top. It turns out that JQ1 shuts off transcription of c-myc, myc being one of these elusive oncogenes that everyone recognizes as one of the major drivers of human cancer. This drug was working through this classically "undruggable" target. This was like science moving at the speed of light and with maximal excitement. For me, as a young scientist here, this was a career-changing moment. We published this result in Nature in 2011.

Another key detail of all this work is that it's been highly reproducible in independent laboratories. Similar work done in Tony Kouzarides' laboratory at Cambridge using a JQ1 molecule that GlaxoSmithKline had developed showed the exact same findings. Since then Pharma has replicated these results widely, which is probably the most important detail in all of this. This has led to the rapid movement of these molecules into clinical trials, I think purely because of the replicability of the finding.

Paula Kiberstis: Can you tell us a little bit about how this protein works? Can you tell us what a bromodomain is and what it does to affect transcription?

Dr. Vakoc: Bromodomains are protein domains that bind to chromatin histones, but only when they're modified chemically by lysine side-chain acetylation. We call them chromatin reader domains. The fascinating thing is that this is a protein-protein interaction surface. JQ1, this really remarkable chemical probe, works not by inhibiting an enzyme (which is how a lot of cancer drugs work), but by inhibiting how proteins interact with one another. Basically, when cells are pulsed with JQ1, it causes BRD4 to lift off of chromatin by binding competitively to the bromodomain pockets.

Paula Kiberstis: Do you know the mechanism by which it has an antileukemic effect? Also, why would you expect this molecule to selectively affect cancer cells and not normal cells?

Dr. Vakoc: These are the central questions in our laboratory. We're making progress, but we still do not have a solid answer. My background is in biochemical mechanisms and transcription. This project, for me, is really an anomaly because there was this fascinating therapeutic response without a mechanism that's been the source of the excitement. Now, we're working backward to try to figure out why this actually works. The short answer is that we don't really understand this very well. When we target BRD4 with molecules, transcription changes in cancer cells, transcription changes in normal cells. Cancer cells don't like it as much as normal cells do. That is probably the most accurate way I can describe this at this point.

Of course, there are molecular details that are fascinating for how this protein works. We've taken the plunge into trying to decipher every nugget of how BRD4 executes its function in leukemia cells. The gist of it is that the genes that are changed when you target BRD4 are genes like $m y c$ : a lot of genes that cancer cells are very dependent on. I suspect that JQ1 stresses cancer cells by withdrawing a lot of the key ingredients necessary to maintain a transformed cell state. Nontransformed cells are not as dependent on the genes that JQ1 suppresses. It's more mysterious than it is understandable at this point.

Paula Kiberstis: How is the drug doing in clinical trials?

Dr. Vakoc: I have very little involvement in those trials. We work very much on the basic side of finding targets. Many independent Pharma groups have made molecules like JQ1, but it's not JQ1 itself. Jay Bradner, in his laboratory, made a drug-like derivative of JQ1 and started a small biotechnology company to move these into clinical studies. GlaxoSmithKline and other groups moved into trials starting in 2013. Several of these are in relapsed patients with refractory acute leukemia that have failed prior chemotherapies.

The first trial was led by a company called OncoEthix using a molecule in the same chemical series as JQ1. A few months ago in The Lancet Haematology, they reported that the molecule, OTX015, is actually quite well tolerated at certain doses. Furthermore, at those welltolerated doses there's some initial evidence with a subset of leukemia patients experiencing complete remission of their disease following single-agent therapy with this molecule. We've been enormously excited to see these early lines of evidence. It's also crystal clear though that this molecule is not Gleevec. The responses were not durable; the patients very quickly relapsed, so it's bittersweet in a way.

Paula Kiberstis: Tumor cells are very smart; they always figure out a way to get around whatever you're doing to them. Are there ways to work out the mechanisms of resistance?

Dr. Vakoc: This has become an area of intense interest in the last year. I think everyone knew resistance would occur. The field is at the stage of trying to figure out what the resistance mechanisms will be. Several reports have found mechanisms in various contexts; they're all different. The mechanisms of resistance appear at this stage to be nongenetic; it looks to be a kind of rewiring of gene expression through what seem to be a multitude of different ways. 
As one would expect from a target like JQ1, the mechanisms of resistance are equally complicated, if not more so, than the actual mechanism of action. The challenges are many at this stage, but one is to predict which patients might be most sensitive to these drugs. The predictive biomarker is kind of the
Holy Grail of this field - that, and the right combination therapies that will synergize and allow these responses to be more durable. This is an area that we, and many others, are pursuing to see whether these molecules can make a real impact on the management of this disease. 


\section{$\$_{\text {CSH\& }}^{\infty}$ Cold Spring Harbor Symposia SYMPOSIA}

\section{A Conversation with Christopher Vakoc}

Cold Spring Harb Symp Quant Biol 2016 81: 344-346 originally published online January 25, 2017

Access the most recent version at doi:10.1101/sqb.2016.81.031617
Creative This article is distributed under the terms of the
Commons http://creativecommons.org/licenses/by-nc/4.0/, which permits reuse and
License redistribution, except for commercial purposes, provided that the original author and source are credited.

Email Alerting Receive free email alerts when new articles cite this article - sign up in Service the box at the top right corner of the article or click here. 